\title{
New Anxiolytic Phytopharmaceutical Elaborated with the Standardized Extract of Galphimia glauca
}

\author{
Jaime Tortoriello, Armando Herrera-Arellano1, \\ Maribel Lucila Herrera-Ruiz, Alejandro Zamilpa, \\ Manases González-Cortazar and \\ Jesús Enrique Jiménez-Ferrer \\ Centro de Investigación Biomédica del Sur, \\ Instituto Mexicano del Seguro Social (IMSS), \\ Xochitepec, Morelos, \\ ${ }^{1}$ Facultad de Medicina, Universidad Autónoma del \\ Estado de Morelos, Cuernavaca, Morelos \\ México
}

\section{Introduction}

From ancient times, medicinal plants have played an important role in the treatment of diseases, especially in those related with the central nervous system (CNS). The study of opium properties (Papaver somniferum), marijuana (Cannabis sativa L.), mandragora (Mandragora officinarum L.), ayahuasca (Banisteriopsis caapi Spruce ex Griseb.), and peyote (Lophophora williamsii (Lem.) Coult.), among others, experienced an important boom during the 1960s and 1970s (Shultes \& Hofmann, 2008). This research work was oriented toward discovering and demonstrating certain pharmacological properties in these plant species. However, the fascinating success of these investigations was the Identification of very interesting chemical compounds that were useful as pharmacological tools for the study of the CNS (Tortoriello, 1999). From plant species, it has been possible to obtain chemical compounds that have been the basis of the development of chemical pharmaceuticals, such as reserpine, morphine, atropine, caffeine, and physostigmine (McClatchey et al., 2009). Over the past several years, in some countries and continuing to refer to Western medicine, phytopharmaceuticals products (containing plant extracts) have been developed. Phytopharmaceuticals, recognized in some countries as officially accepted drugs, are products in which identification of the active compounds has been reached and in which effectiveness, tolerability, and safety have been demonstrated by means of controlled clinical trials (Tortoriello et al., 2003). The following phytopharmaceuticals with CNS properties have been used broadly worldwide: Valeriana officinalis, prescribed principally for the treatment of insomnia (Salter \& Brownie, 2010); Hypericum perforatum, the extract obtained from its roots is used for producing phytopharmaceuticals useful for treatment of mild to moderate depression (Kasper et al., 2010), and Ginkgo biloba, a widely recognized plant species due to its properties of improving cerebral blood flow and because of its effect on 
memory disorders (Mashayekh et al., 2010). Regarding anxiety, it has not been easy to discover plant species with demonstrated selective activity without the evidencing of side effects. Piper methysticum G. Forster (Kava Kava) is a plant originally from Oceania (Polynesia, Micronesia, and Melanesia) from which a very important anxiolytic phytopharmaceutical was developed. Despite that the pharmacological mechanism of action has not been identified, pharmaceutical products elaborated from P. methysticum root extract were evaluated in clinical trials in which an anxiolytic effect, different from that produced by benzodiazepines, was demonstrated (Gastpar \& Klimm, 2003). Different double-blind clinical studies compared the effects produced by $P$. methysticum against placebo in patients with a diagnosis of nonpsychogenic anxiety and in women with menopause-associated anxiety. The phytopharmaceuticals produced with this plant extract achieved wide commercial success in Europe and in some countries on the American Continent. However, due to reports of some cases of hepatotoxicity, pharmaceutical products elaborated with this extract were withdrawn from the market in different countries. Recent studies, performed after the warning report, have continued to evaluate this product therapeutically (vs. buspirone and opipramol), but several studies have had the purpose of evaluating the toxicological effects (Teschke et al., 2011). At present, P. methysticum is out of the formal ethics pharmaceutical market in the majority of countries.

\section{Ethnomedical use of Galphimia glauca in Mexican Traditional Medicine}

Galphimia glauca Cav., of the Malpighiaceae family, is a medicinal plant native to Mexico that is commonly known with the name of "Calderona amarilla" (Figure 1). Although there are no written documents, it has been known that from past times, this plant species has been employed in Mexican Traditional Medicine as a sedative and a tranquilizer for persons with insanity. The tranquilizing properties of this plant were also utilized during the "Cristeros" War (1926-1929) in Mexico; soldiers who had profuse diarrhea, severe paleness, and fear of going to battle received an infusion prepared with the leaves and stems of this plant, which afforded them great tranquility and the disappearance of nervous diarrhea.

Galphimia glauca is a shrub that is widely distributed throughout Mexico due to its resistance to environmental conditions. Native to central Mexico, this evergreen plant has been known since pre-Columbian times. The Nahuatl people used the "totoncapatly" voice when referring to this shrub. Such an expression derives from the words "totonqui" and "patli", which mean "hot" and "medicine", respectively, in Nahuatl (Tortoriello, 1998).

\section{Preliminary pharmacological studies of G. glauca extracts on the CNS}

Based on the traditional medical use of this species, the methanolic extract of the aerial parts of the plant was evaluated in five neuropharmacological animal models. In all of these, the results obtained suggested a CNS depressor effect. The extract significantly potentiated the hypnotic effect induced by sodium pentobarbital in mice and reduced the effect of stimulant drugs administered in mice, such as strychnine and leptazol, producing in the animals an increment in the latency time of convulsions and diminishing the number of animals with convulsions, as well as mortality. Another depressor action was observed on the body temperature of the animals; administration in normothermic rats lowered the body temperature in a highly significant manner. On the other hand, it was demonstrated that $G$. glauca also depressed neuronal groups in in vitro isolated Guinea-pig ileum (Tortoriello \& Lozoya, 1992). 


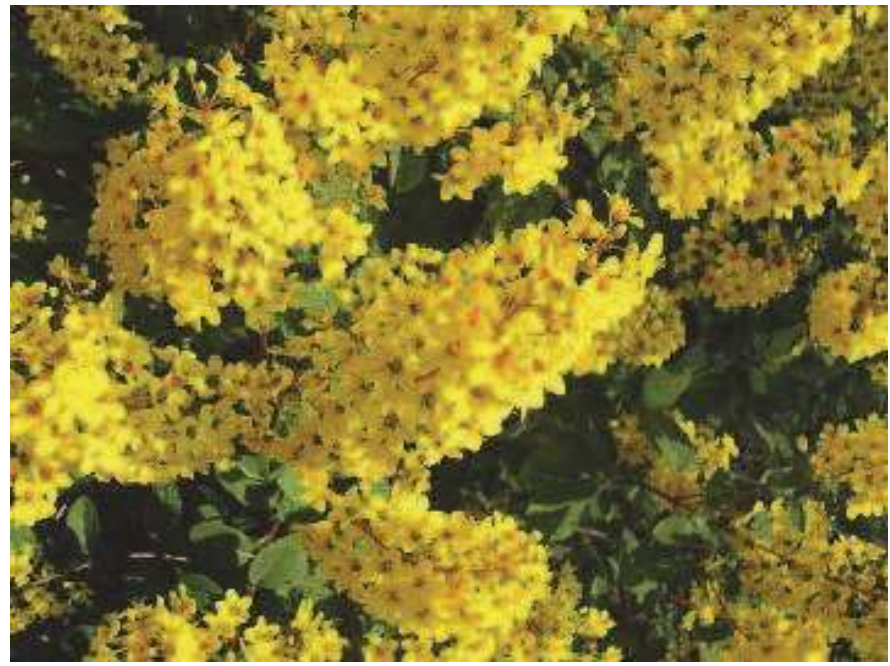

Fig. 1. Galphimia glauca Cav. growing in a controlled crop.

\section{Chemical isolation and identification of the active compound}

By means of bioguided phytochemical separation, isolation was achieved of an active molecule whose structural elucidation demonstrated a nor-seco-triterpene. This compound is made up of 30 carbons organized in four rings with six members each, and a seventh member, hetero-cycle ring. Structurally, this compound comprises (4R)-Trihydroxy-13amethoxycarbonyl-30-nor-3,4-seco-7a,18 $\beta$-fridela-1,20-dien-3,24-olide, a new compound that received the trivial name of Galphimine-B or G-B (Figure 2). Chemical characterization was reached through exhaustive nuclear magnetic resonance (NMR) spectroscopic analysis of ${ }^{1} \mathrm{H}$ and ${ }^{13} \mathrm{C}$, as well as x-ray diffraction of the crystallized compound (Toscano et al., 1993).

Other compounds, with similar structures, have been isolated from the active extract. These compounds also present the six-ring structure with the seventh hetero-cycle member, but with different functional groups (Figure 2). All of these, known as Galphimines, have shown to possess less activity than G-B (González-Cortázar et al., 2005).

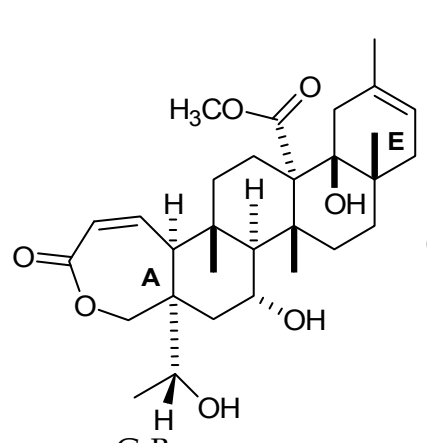

G-B

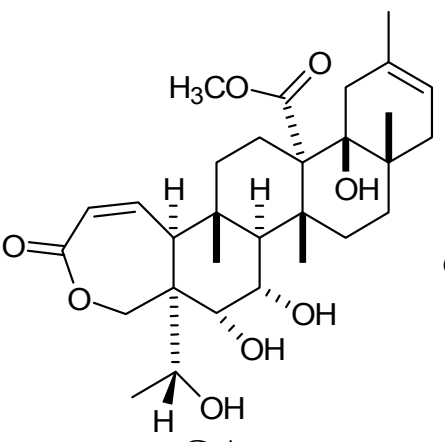

G-A

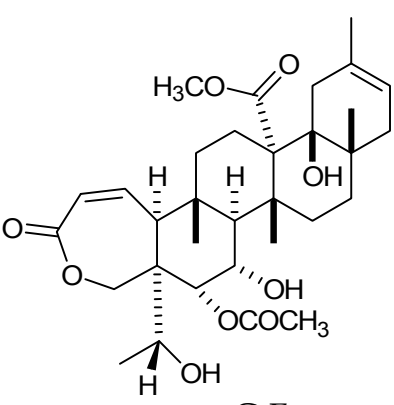

G-E

Fig. 2. Chemical structure of Galphimine- B (G-B), Galphimine-A (G-A), and Galphimine-E (G-E). 


\section{Anxiolytic effect and mechanism of action}

\subsection{Anxiolytic effect of metanolic extract from Galphimia glauca}

In an assay carried out in ICR-strain male mice, it was demonstrated that the administration of increasing doses of the methanolic extract of Galphimia glauca $(125,250,500,1,000$, and $2,000 \mathrm{mg} / \mathrm{kg}$ via oral route) caused a significant increase in animals in terms of the percentage of time that the mice remained on the open arms of the elevated plus maze (EPM), as well as also an increase in the percentage of number of crossings that the mice carried out toward these arms $(p<0.05)$ (Figure 3 ). The data were compared with the group that only received a Tween 20 solution at $5 \%$ (vehicle, $10 \mu \mathrm{l} / 10 \mathrm{~g}$ of the weight of the mouse). The G. glauca extract utilized in this model was standardized in its G-B content, establishing that it contained $8.3 \mathrm{mg} \mathrm{G}-\mathrm{B} / \mathrm{g}$ of extract. As described in the literature (Rex et al., 2002), diazepam at $1.0 \mathrm{mg} / \mathrm{kg}$ was capable of inducing a significant increase in comparison with the control group $(p<0.05)$ in the parameters previously cited, this indicative of pharmacological model validation (Herrera-Ruiz et al., 2006A).

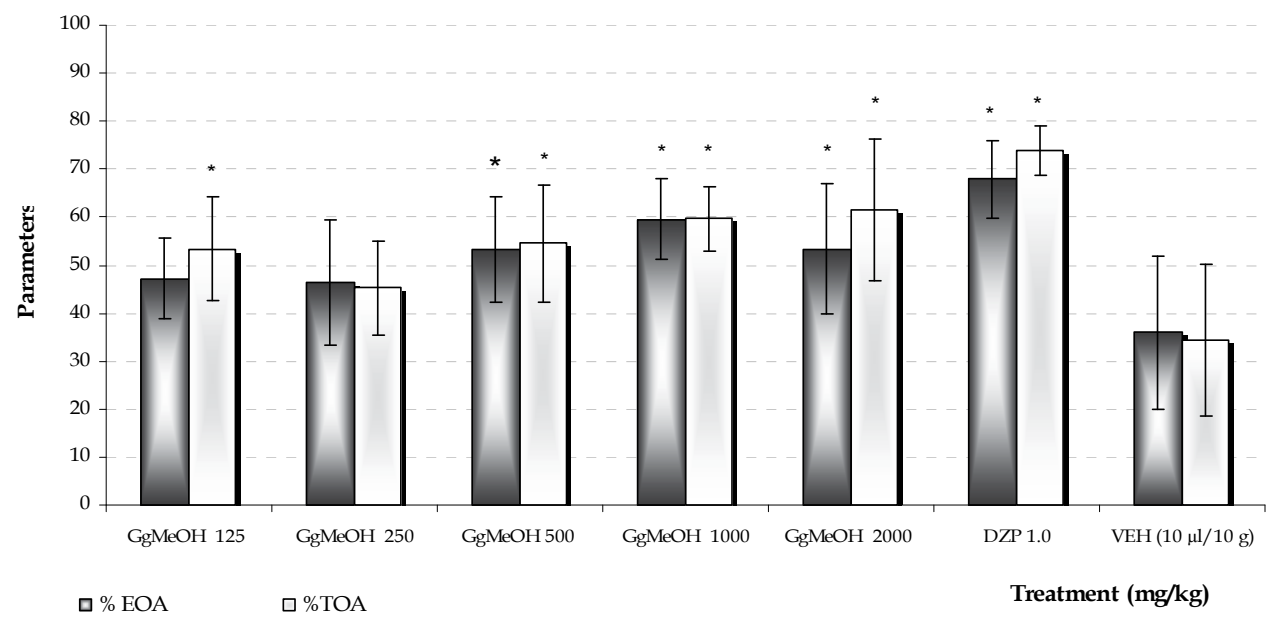

Fig. 3. Effect produced by different doses of methanolic extract from Galphimia glauca on ICR mice exposed to the elevated plus maze paradigm. ${ }^{*}<<0.05$ with ANOVA followed by posthoc Dunnett test (mean \pm Standard deviation [SD]; $n=7$ ). DZP = diazepam; VEH = Vehicle (solution of Tween 20 at 5\%). \%EOA = mean percentage of the number entries on the open arms of the EPM; \% TOA = mean percentage of time spent on the open arms of the EPM.

It has been proposed that adequate interpretation of the results in the EPM should be accompanied by an analysis of the ethological parameters that improve the model's sensitivity and that allow for identification of the emotional changes in the animals (Cole \& Rodgers, 1994). These parameters can be confounder factors predicting the anxiolytic capacity of the treatments. In this way, it is suggested that within the EPM, it would be necessary to analyze the ethological measurements of Head dips (HD) (Weiss et al., 1998). Thus, for example, the increase in the number of HD on open arms is a behavior that is inversely correlated with the level of anxiety. This means that the more HD performed by the animals, the less anxiety demonstrated; this is a risk appraisal parameter, and this behavior is reported for substances such as diazepam (Cruz et al., 1994; Rodgers \& Johnson, 
1995). In the case of the administration of the methanolic extract of G. glauca, the number of HD was significantly greater $(p<0.05)$ than that of the group that only received the vehicle; this parameter increased in a dose-dependent manner (Table 1). On the other hand, similar behavior was observed in the group of animals that received benzodiazepine .

Vertical exploration, or Rearings ( $\mathrm{R}$ ) is commonly accepted as a measurement of locomotor activity (Ramos et al., 1997). A decrease in the number of $R$ can be related with the reduction in crossings to closed arms, where this behavior regularly occurs. It has been observed that diazepam causes a diminution in mice of the number of $R$, thus associating this with a diminution in the number of entrances on the closed arms. This behavior is in agreement with the results obtained with the increasing administration of the standardized G. glauca extract and also with diazepam; both treatments induce a significant diminution of $\mathrm{R}$ with respect to the vehicle $(p<0.05)$ (Table 1$)$.

In addition to the effect observed in the EPM model, we also evaluated the standardized extract of G. glauca (different doses) on the Light/dark model; this is a paradigm based on the rejection of rodents to travel through the brilliantly illuminated areas and on their spontaneous exploratory behavior in the face of the novelty of the environment (Crawley \& Goodwing, 1980). It has been determined that this test is useful in predicting the anxiolytic or anxiogenic capacity of different treatments. Benzodiazepines and serotonergic drugs can be detected as anxiolytics employing the Light-dark methodology (Hascoët et al., 2001).

\begin{tabular}{|c|c|c|}
\hline Treatment doses & HD & R \\
\hline G. glauca 125 & $29.3 \pm 6.6^{*}$ & $14.5 \pm 2.5^{*}$ \\
\hline G. glauca 250 & $29.5 \pm 3.6^{*}$ & $13.3 \pm 1.8^{*}$ \\
\hline G. glauca 500 & $34.4 \pm 7.1^{*}$ & $15.1 \pm 2.9^{*}$ \\
\hline G. glauca 1,000 & $35.1 \pm 7.9^{*}$ & $12.8 \pm 3.7^{*}$ \\
\hline G. glauca 2,000 & $39.1 \pm 6.3^{*}$ & $10.4 \pm 4.8^{*}$ \\
\hline DZP 1.0 & $51.0 \pm 12.0^{*}$ & $13.4 \pm 2.1^{*}$ \\
\hline VEH $(10 \mu \mathrm{l} / 10 \mathrm{~g})$ & $13.7 \pm 3.3$ & $23.6 \pm 2.8$ \\
\hline
\end{tabular}

Data presented as means \pm Standard error of mean [SEM] with $n=7,{ }^{*} p<0.05$ compared with control using Analysis of variance (ANOVA) and post-hoc Dunnett test. HD = Head-dips; $R=$ Rearings.

Table 1. Ethological parameters recorded in the Elevated plus maze (EPM) with different doses $(\mathrm{mg} / \mathrm{kg})$ of the methanolic extract from Galphimia glauca

In this model, the different dosages of the standardized extract of G. glauca induced a significant increase in the time that the mice spent in the illuminated compartment, thus indicative of an anxiolytic effect; the data obtained with this treatment were similar to those yielded by the group of mice who received diazepam at $1.0 \mathrm{mg} / \mathrm{kg}$ (Figure 4).

With the models of the EPM and the Light/dark compartment, it was able to be demonstrated that the standardized G. glauca extract possesses an anxiolytic effect in the pre-clinical experimentation phase.

\subsection{Anxiolytic effect produced by the isolated Galphimines}

From the active extract of Galphimia glauca, we obtained samples of pure Galphimines. The authenticity of the G-B, G-A, and G-E compounds were confirmed by NMR spectroscopy tests of ${ }^{1} \mathrm{H}$ and ${ }^{13} \mathrm{C}$. We also included, for comparative purposes, a sample that contained the three Galphimines together: G-B, G-A, and G-E, but without other compounds of the whole 
extract (fraction of Galphimines, GRF). Intraperitoneal (i.p.) administration of G-B, G-A, and the GRF at a dose of $15 \mathrm{mg} / \mathrm{kg}$ produced, in male mice, a significant increase in the percentage of time that the animals spent on the open arms and percentage of number of crossings in these arms; this behavior was similar to that observed in the group that received diazepam at $1.0 \mathrm{mg} / \mathrm{kg}$, but significantly different from that of the group that received the vehicle $(10 \mu \mathrm{l} / 10 \mathrm{~g}$ of weight of Tween 20 solution at $5 \%)(p<0.05)$ (Figure 5) (Herrera-Ruiz et al., 2006B).

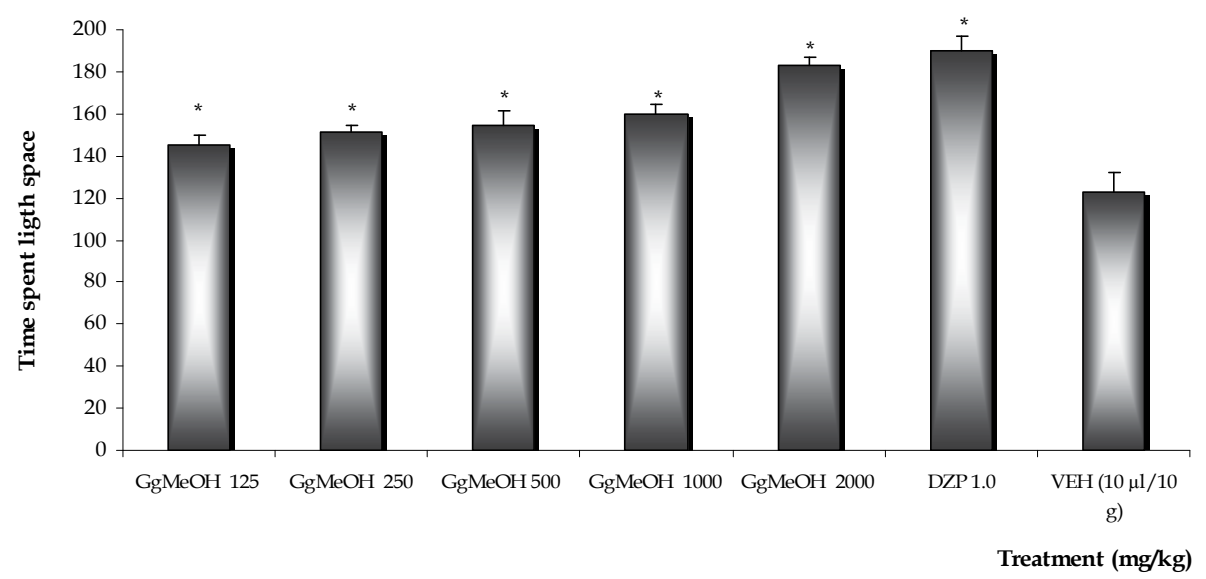

Fig. 4. Effect produced by different doses of the methanolic extract from Galphimia glauca on the time spent by ICR mice in the illuminated compartment in the Light-dark test. ${ }^{*} p<0.05$ with Analysis of variance (ANOVA) followed by post-hoc Dunnett test (mean \pm Standard deviation [SD]; $n=7$ ). DZP = diazepam; $\mathrm{VEH}=$ Vehicle (solution of Tween 20 at 5\%).

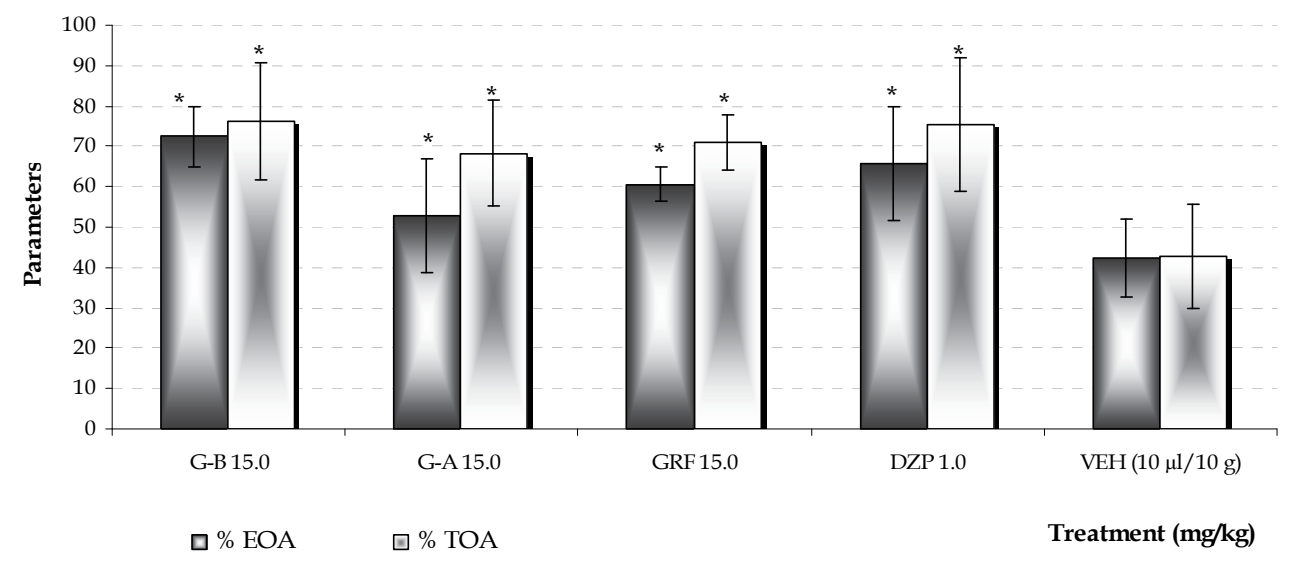

Fig. 5. Effect produced by G-B, G-A, and the pool of Galphimines on ICR mice exposed to the elevated plus-maze paradigm. ${ }^{*} P<0.05$ with Analysis of variance (ANOVA) followed by post-hoc Dunnett test (mean \pm Standard deviation $[S D] ; n=7)$. DZP = diazepam; VEH = Vehicle (solution of Tween 20 at $5 \%$ ). 
The ethological parameters associated with the evaluation of the number of crossings and the percentage of time on open arms was also registered for this assay. As can be observed in Table 2, the number of HD is significantly greater for animals treated with G-B, G-A, the GRF, and diazepam when statistically compared with the control $(p<0.05)$. In agreement with these data, we observed a statistically different diminution in the $\mathrm{R}$ parameter for all anxiolytic treatments in comparison with the vehicle $(p<0.05)$ (Table 2$)$.

\begin{tabular}{|c|c|c|}
\hline TX/doses & Head dips & Rearings \\
\hline G-B 15 & $45.5 \pm 12.32^{*}$ & $6.3 \pm 2.34^{*}$ \\
\hline G-A 15 & $33.2 \pm 7.31^{*}$ & $13.3 \pm 2.94^{*}$ \\
\hline Pool 15 & $37.2 \pm 7.56^{*}$ & $9.2 \pm 3.8^{*}$ \\
\hline DZP 1.0 & $44.1 \pm 10.49^{*}$ & $9.62 \pm 4.1^{*}$ \\
\hline VEH $(10 \mu \mathrm{l} / 10 \mathrm{~g})$ & $25.6 \pm 4.53$ & $22.2 \pm 6.9$ \\
\hline
\end{tabular}

Data presented as means \pm Standard error of mean [SEM] with $n=7 ; * P<0.05$ compared with control using Analysis of variance (ANOVA) and post-hoc Dunnett test.

Table 2. Ethological parameters recorded in the Elevated plus maze (EPM) with different Galphimines (mg/kg) from Galphimia glauca

The data accumulated on the anxiolytic activity of the standardized extract of G. glauca and its triterpenic derivatives show that this Mexican medicinal species possesses effects of central depression, whose action on animal models induces behavior similar to that of substances that are clinically utilized as main therapeutic resources for treating illnesses such as anxiety, as is the case of benzodiazepines.

\subsection{Action mechanism of G-B}

Pure G-B has been evaluated in different pharmacological tests. These results showed that this compound, administered i.p. in mice, did not exhibit any significant effect as an anticonvulsant; however, it was able to increase significantly the hypnotic effect induced by sodium pentobarbital on mice in a dose-dependent manner. This compound also produced strong inhibition of the electrically-induced contraction of Guinea-pig ileum (Tortoriello \& Ortega, 1993). These results suggested that the effect produced by G-B is not manifested in generalized motor processes, for example, in protection against induction of convulsion in mice. However, the pharmacological effect is observed in motor activities directed toward an objective as a goal, such as occurs with stereotypic-activity localization and adaptation in novel environments or in specific behaviors such as hypnosis induction in mice. These data supported, from that time, the idea of a selective action mechanism, particularly on regions that regulate motivational behaviors that are implicated in the processes of punishment and reward with a strong motor component. With these bases, the interaction of G-B with some of the cerebral stem structures was explored. Receptor binding experiments did not demonstrate any affinity of G-B with clonazepam, diazepam, or opioid receptors. Unexpectedly, extracellular unitary neuronal records in whole animals showed that G-B modified, with specificity, the electrical activity of ventral tegmental area (VTA) neurons in rats (Tortoriello et al., 1998). It was also observed that the inhibitory effect produced by G-B on the frequency of discharge takes place only in neurons with specific discharge patterns. The effect was observed on neurons with low frequency with periodic and rhythmic burst discharges, compatible with dopaminergic neurons. In general, G-B inhibits the activity of 
the mesencephalic dopaminergic pathways. Intracellular records in brain slices showed that G-B inhibits the excitatory postsynaptic potentials; this effect was similar to that produced by GABA and clonazepam (Prieto Gómez, et al., 2003). Nonetheless, the effect produced by G-B was not blocked by bicuculline, picrotoxin, or flumazenil, thus providing an action mechanism independent of the GABA-A receptor.

\section{Evaluation of the toxic activity of extracts obtained from Galphimia glauca}

The safety of the G. glauca anxiolytic extract has been evaluated in pre-clinical toxicology assays using rodents under a chronic administration scheme. Determination of the possible toxic effects of this medicinal species was conducted with different extracts with the purpose of conciliating, on the one hand, the greatest efficacy of the extract with the least number of side effects, or, in the best of cases, the absence of the latter (Aguilar-Santamaría et al., 2007).

After oral administration of the $2.5 \mathrm{~g} / \mathrm{kg}$ dose of the aqueous, methanolic, and ethanolic extracts of G. glauca in a 28-day daily scheme to Balb-C mice of both genders, it was performed an evaluation on the liver, due to that administration via oral route ensures the passage of this phytopharmaceuticals through this organ by means of the portal circulation. Based on the anatomic position between the gastrointestinal tract and systemic circulation, the liver plays an important role in the metabolism of exogenous substances (GrosseSiestrup et al., 2002). The hepatotoxic effects produce tissue alterations accompanied by the liberation of the cellular contents into the plasma, such as the Alanine aminotransferase enzyme (ALT), the Aspartate aminotransferase enzime (AST), and the Alkaline phosphatase enzyme (ALP), which takes place after an acute inflammatory process and which is eventually related with the oxide-reduction equilibrium of the hepatocytes (Stirnimann et al., 2010). The results of the serum analysis of these enzymes, in the different groups of mice with the extracts administered, show that there are no changes in the activity of these with respect to the control group, which suggests a lack of liver damage (Figure 6).

As a complementary analysis, it is important to evaluate the neurotoxicological component by means of the observation of the Animal's behavior. For this, it was daily observed the behavior and the physiological state of the mice, initially described by Samuel Irwin (Irwin, 1968). With this method, it was evaluated consciousness, mood state, motor activity, CNS excitation, posture, motor coordination, muscular tone, reflexes, and autonomic competence. Chronic administration of the extracts of G. glauca caused changes in the behavior of the mice. In special fashion, the methanolic extract produced piloerection, loss of equilibrium, and diminution in the straightening reflex, without modification of other signs, such as tearing, modification of the diameter of the pupil, respiratory movements, paralysis, and diminution of prehensile activity. Dehydration was also observed, as a consequence of treatment, which can be associated with a possible non-quantified diuretic effect, while it cannot be associated with diarrheic evacuations. These changes can be due to a potent depressor effect of the CNS produced by the prolonged administration time of the extracts at doses as high as $2.5 \mathrm{~g} / \mathrm{kg}$ (Aguilar-Santamaría et al., 2007).

The therapeutic safety of the extracts of Galphimia glauca was also analyzed through the cytotoxicity technique on cell lines cultured in vitro as follows: colon cancer (HCT-15); uterine cervix cancer (UISO); human nasopharyngeal cancer (KB), and ovarian cancer (OVACAR-5). Determination of the cytotoxic effect was based on quantification of the concentration of proteins at the end of treatment (Oyama \& Tagle, 1956), and results were expressed as the concentration that inhibited $50 \%$ of growth of the control treatment $\left(\mathrm{EC}_{50}\right)$. Values were 
estimated on the semi-log graph of the concentration of the extract $(\mu \mathrm{g} / \mathrm{ml}) \mathrm{vs}$. the percentage of viable cells. The data indicated that the three extracts from Galphimia glauca did not induce cytotoxicity on the cell lines derived from nasopharyngeal tissue (KB), uterus (UISO), and ovary (OVCAR-5), in which the $\mathrm{EC}_{50}$ was $<2 \mu \mathrm{g} / \mathrm{ml}$. The cytotoxic effect was only apparent with the colon line (HCT-15), in which $\mathrm{ED}_{50}$ values were $0.63,0.50$, and $1.99 \mu \mathrm{g} / \mathrm{ml}$ for the ethanolic, methanolic, and aqueous extracts, respectively (Aguilar-Santamaría et al., 2007).
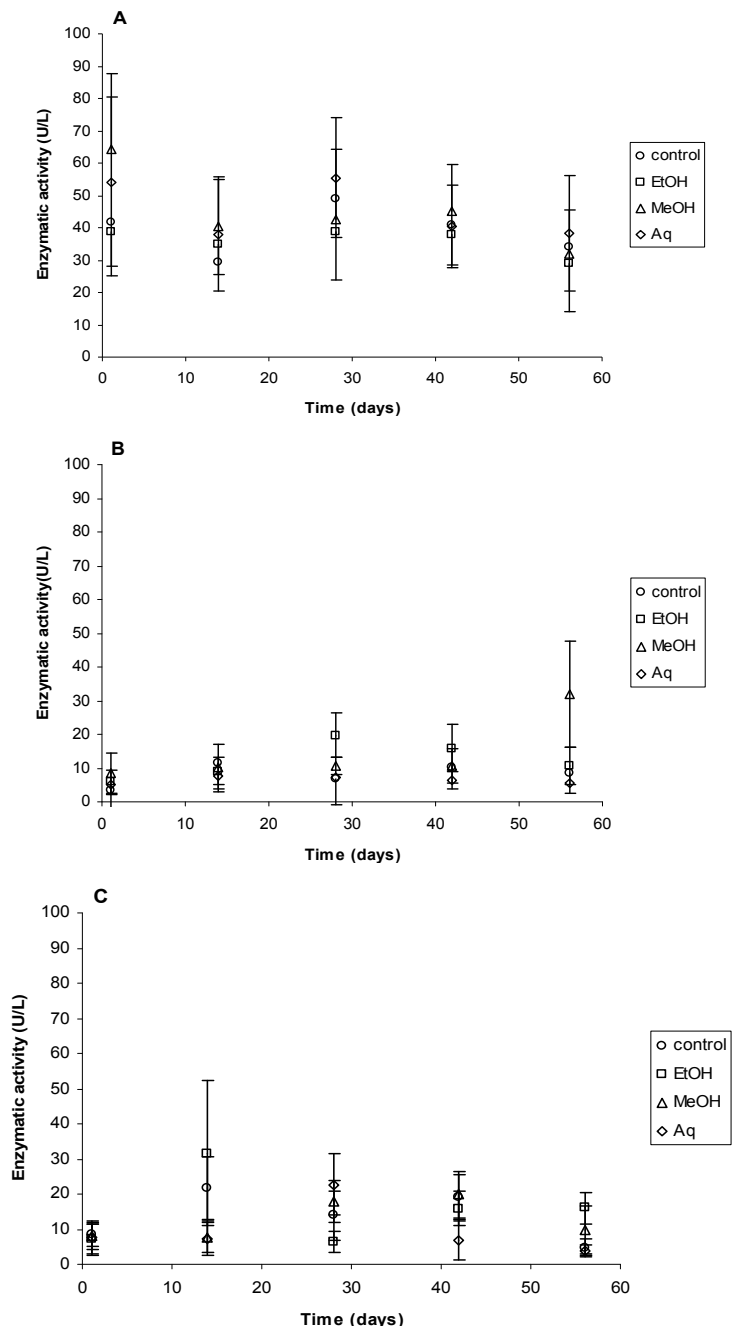

Fig. 6. Enzymatic activities in serum of Alkaline phosphatase (ALP, panel A), Alanine aminotransferase (ALT, panel B), and Aspartate aminotransferase (AST, panel C) of mice exposed for 56 days to the ethanolic, methanolic, and aqueous extracts of Galphimia glauca. The results are expressed as means \pm Standard deviation (SD); analysis was carried out by means of Analysis of variance (ANOVA) and the Bonferroni post-test. Statistical significance was $p<0.05$. 
Another safety parameter was evaluated by means of the genotoxicity technique in the peripheral lymphocytes of healthy volunteers; the cells were cultured with increasing concentrations of G. glauca extracts and the results were compared with the negative (saline solution at $0.9 \%$ ) and the positive control (cyclophosphamide, $0.025 \mu \mathrm{l} / \mathrm{ml}$ ). The culture was maintained for $72 \mathrm{~h}$ under standard maintenance conditions; at the end, a smear was carried out that stained with Wright stain and these were observed under the microscope (Perry \& Wolf, 1974) in order to observe the sister chromatids and the presence of micronuclei; 10,000 lymphocytes were evaluated under the optical microscope with criteria defined by Fenech (2000). The data indicate that under this design, none of the extracts caused a genotoxic effect (Aguilar-Santamaría et al., 2007).

The content of Galphamines was quantified in each of the three extracts (Table 3).

\begin{tabular}{ccc}
\hline Extract & Compound & Concentration $(\mathrm{mg} / \mathrm{g})$ \\
\hline \multirow{3}{*}{ Aqueous } & G-A & 0.6 \\
& G-B & 1.034 \\
& G-E & 1.12 \\
\hline \multirow{3}{*}{ Methanolic } & G-A & 7.29 \\
& G-B & 17.47 \\
& G-E & 13.6 \\
\hline \multirow{2}{*}{ Ethanolic } & G-A & 5.35 \\
& G-B & 18.8 \\
& G-E & 17.49 \\
\hline
\end{tabular}

Table 3. Galphmine content, extraction yield, and chromatographic analysis in High performance liquid chromatography (HPLC) of the different Galphimia glauca extracts

\section{Effectiveness and tolerability of a phytopharmaceutical containing the standardized extract of G. glauca on patients with generalized anxiety disease}

Based on the findings of the anxiolytic pharmacological activity of the plant species Galphimia glauca, and with the intention to propose a new alternative for the treatment of the generalized anxiety disorder (GAD), a phytopharmaceutical was generated from a dry extract from the aerial parts of this plant species, standardized in its G-B content (active compound). In this manner, to initiate the systematic study of the novel phytopharmaceutical, it was proposed the generation of clinical evidence on its safety and therapeutic effectiveness in patients with GAD, comparing it against a widely used drug belonging to the group of benzodiazepines (Herrera-Arellano et al., 2007).

The raw material or plant drug was obtained from a controlled culture generated by means of micropropagation in an experimental field localized in Xochitepec, Morelos, Mexico. The culture was supervised in accordance with good agricultural practices (OMS, 2003). A sample was identified by Abigail Aguilar-Contreras, M.Sc., and deposited in the Medicinal Herbarium of the IMSSM as reference. The plant raw material, leaves and stems, was dried under conditions of darkness, at room temperature, for a 2-week period; later, this was triturated and ground until we obtained 1-3-mm particles, which were stored in hermetically sealed containers until use. 
The extract that was employed to formulate the phytopharmaceutical was obtained by maceration in water at $60^{\circ} \mathrm{C}$ for $2 \mathrm{~h}$. The liquid extract was dried in two phase: the first, by distillation at reduced pressure (Heidolph, Laborota 20), and later, by a spray-dry system. The dry extract was collected and stored at $4^{\circ} \mathrm{C}$ until formulation of the phytopharmaceutical. Chromatographic analysis by HPLC of the extract indicated that the drying system did not modify the concentration of G-B. The final yield of the extraction process was $5 \%$, and each $\mathrm{g}$ of the extract contained $1.12 \mathrm{mg}$ of G-B.

The experimental treatment corresponding to the G. glauca pharmaceutical was formulated in hard gelatin capsules. Each capsule contained $310 \mathrm{mg}$ of dry extract, at least $0.350 \mathrm{mg}$ of G-B/capsule, and $500 \mathrm{mg}$ of vehicle; the capsules were packed individually in blister packs of 10 units each. Several methodologies on the previously lacked drug for quality control were carried out, based on Official Mexican Norms: NOM-059-SSA1-1993 and NOM-073SSA1-1993. Additionally, the analyses were conducted according to the Pharmacopoeia of the United Mexican States [2004]. The control treatment was formulated with $1.0 \mathrm{mg}$ de lorazepam, with the same pharmaceutical presentation, packaging, and quality as the experimental drug.

\subsection{Description of the clinical study}

With the authorization of and registry number 2003-322-0010 of the Mexican Institute of Social Security (IMSS) Ethics and Research Committee, adult, ambulatory males and females between the ages of 18 and 65 years where included in the study. Patients must reunite the DSM IV diagnostic criteria for GAD, and a Hamilton (HAM-A) scale score $\geq 19$ points, without pharmacological treatment in the month prior to their inclusion. In addition, the subjects could not present a history of current use, for at least 6 months previously, alcohol or drug addiction or abuse, nor data of suicidal ideation or of another psychiatric pathology that was clinically more relevant than GAD, and the signing of a letter of informed consent Clinical, randomized, double-blind and controlled study was carried out at the Hospital General of the IMSS in Cuernavaca, Morelos, Mexico. The experimental group was treated with capsules containing the aqueous and the dry extract of G. glauca (standardized in 0.350 $\mathrm{mg}$ of G-B) at a dose of one capsule every $12 \mathrm{~h}$ for 4 continuous weeks. The control group received $1.0 \mathrm{mg}$ of lorazepam at the same dose. The main outcome variable, therapeutic effectiveness, was considered when the HAM-A scale score was $<18$ points. Secondary variables included tolerability (the absence of intense or severe sedation, which merited treatment suspension) and therapeutic safety (at the end of the study, the absence of pathological alterations in the biochemical tests of hepatic and renal function: ALT; AST, serum urea, and serum creatinine). In addition, from week 1 of treatment, we implemented two scales to appraise the therapeutic effect of the treatment assigned by means of the scales denominated Global patient evaluation (GPE) and Global clinical impression (GCI). Patients were scheduled weekly on four occasions to evaluate the proposed outcomes, the presence of side effects (through a scale designed ad hoc, composed of 50 and additional items that evaluated the severity of these), treatment compliance (ingestion of at least $80 \%$ of the prescribed doses), and resupply of the assigned drug.

To evidence the differences among treatments, the Analysis of variance (ANOVA) test was utilized, a reliable statistical method for comparing continuous variables with normal distribution, while the non-parametric Wilcoxon and Mann-Whitney $U$ tests were employed for comparing paired and independent data, respectively. The $X^{2}$ test served for comparing two proportions; $p$ values $\leq 0.05$ were considered as a significant difference. 


\subsection{Results of the clinical study in patients with GAD}

The study began with 152 patients (72 in the experimental group). Table 4 compares the population characteristics on initiation of the clinical assay; significant differences were not appreciated in any of the parameters evaluated $(p \geq 0.17)$. It is noteworthy that on beginning the study, the average patients age was 37.8 years, with 4.1 years of GAD disease evolution and 29 points on the HAM-A scale; in addition, feminine gender predominated with schooling equal to or greater than high school.

\begin{tabular}{|c|c|c|c|c|c|}
\hline \multirow[t]{2}{*}{ Variable } & \multicolumn{2}{|c|}{ G. glauca $(n=72)$} & \multicolumn{2}{|c|}{ Lorazepam $(n=80)$} & \multirow{2}{*}{$\begin{array}{c}\text { ANOVA } \\
P\end{array}$} \\
\hline & $\mathrm{m}$ & $\mathrm{SD}$ & $\mathrm{m}$ & $\mathrm{SD}$ & \\
\hline Age (years) & 38.38 & 11.13 & 37.35 & 11.49 & 0.57 \\
\hline Weight (kg) & 66.08 & 12.34 & 67.64 & 13.05 & 0.45 \\
\hline Height $(\mathrm{cm})$ & 158.33 & 9.75 & 157.83 & 7.72 & 0.72 \\
\hline BMI $\left(\mathrm{kg} / \mathrm{m}^{2}\right)$ & 26.38 & 4.42 & 27.16 & 4.99 & 0.31 \\
\hline SBP (mmHg) & 114.58 & 10.99 & 114.59 & 10.050 & 0.96 \\
\hline $\mathrm{DBP}(\mathrm{mmHg})$ & 72.62 & 9.90 & 72.31 & 9.34 & 0.84 \\
\hline CF (beats/min) & 79.79 & 4.86 & 79.31 & 7.39 & 0.64 \\
\hline RF (resp/min) & 20.98 & 1.975 & 20.96 & 1.99 & 0.94 \\
\hline \multirow[t]{2}{*}{$\begin{array}{l}\text { GAD evolution } \\
\text { (months) }\end{array}$} & 51.18 & 56.01 & 48.35 & 59.91 & 0.76 \\
\hline & $\bar{F}$ & $\%$ & $\bar{F}$ & $\%$ & $X^{2} p$ \\
\hline Gender & & & & & 0.58 \\
\hline Masculine & 18 & 25.00 & 17 & 21.25 & \\
\hline Feminine & 54 & 75.00 & 63 & 78.75 & \\
\hline School grade reached & & & & & 0.66 \\
\hline$\leq$ Elementary & 34 & 47.22 & 35 & 43.75 & \\
\hline$\geq$ High school & 38 & 52.78 & 45 & 56.25 & \\
\hline Occupation & & & & & 0.88 \\
\hline Homemaker & 26 & 36.11 & 28 & 35.00 & \\
\hline Other & 46 & 63.89 & 52 & 65.00 & \\
\hline Comorbidity & & & & & 0.59 \\
\hline Positive & 24 & 33.33 & 30 & 37.50 & \\
\hline Negative & 48 & 66.67 & 50 & 62.50 & \\
\hline Smoking & & & & & 0.98 \\
\hline Positive & 17 & 23.61 & 19 & 23.75 & \\
\hline Negative & 55 & 76.39 & 61 & 76.25 & \\
\hline Previous alcoholism & & & & & 0.17 \\
\hline Positive & 16 & 22.22 & 11 & 13.75 & \\
\hline Negative & 56 & 77.78 & 69 & 86.25 & \\
\hline Previous drug addiction & & & & & 0.89 \\
\hline Positive & 5 & 6.94 & 6 & 7.50 & \\
\hline Negative & 67 & 93.06 & 74 & 92.50 & \\
\hline
\end{tabular}

$\mathrm{ANOVA}=$ Analysis of variance; $\mathrm{BMI}=$ Body mass index $\mathrm{SBP}=$ Systolic blood pressure $; \mathrm{DBP}=$ Diastolic blood pressure; $\mathrm{CF}=$ Cardiac frequency; $\mathrm{RF}=$ Respiratory frequency; $\mathrm{GAD}=$ Generalized anxiety disease .

Table 4. Comparison of the population characteristics on study initiation. Values correspond to means $(\mathrm{m})$ and Standard deviation (SD), absolute frequencies (f), and relative frequencies $(\%)$ 
During the development of the clinical assay, 38 subjects were excluded, the majority belonging to the lorazepam-treated group $(21,55.26 \%)$. Incapacitating sedation was the main reason for exclusion; this presented in 20 patients, of among whom four belonged to the group treated with the G. glauca phytopharmaceutical. The remaining 18 subjects were excluded due to non-drug-related reasons

For the therapeutic effectiveness analysis, 114 patients, who concluded the entire study, were included. For analyzing tolerability, 20 subjects who were excluded due to incapacitating morning sedation were added. Finally, in the therapeutic safety analysis, 113 patients who concluded the study were included, with the exception of one patient who did not allow a final blood sample to be performed for the programmed biochemical studies.

the therapeutic tolerability analysis, evaluated as morning sedation, exhibited significant differences in favor of the phytopharmaceutical (6.78 vs. $21.33 \% ; \mathrm{X}^{2}, p=0.01$ ), while none of the patients on whom we practiced the programmed laboratory tests showed pathological results; therapeutic safety was $100 \%$ in both groups.

Therapeutic effectiveness was evaluated mainly by means of the HAM-A scale, which was complemented with the EGP and the GCI. It is noteworthy that at the end of the study, both treatments significantly reduced these three scales (Wilcoxon, $p \leq 0.0001$ ). In Figure 7, it may be observed that the two treatments diminished with regard to the HAM-A scale from week 1 and during the subsequent 3 weeks in similar fashion (Mann-Whitney, $p>0.54$ ). Likewise, on concluding the study, there were no significant differences among treatments with this scale. It is noteworthy that the phytopharmaceutical diminished HAM-A from 29 to 9 points $(65.62 \%)$. In addition, at the end of the study, the phytopharmaceutical from G. glauca obtained $80 \%$ anxiolytic effectiveness, while lorazepam obtained $81.3 \%$.

Figures 8 and 9 compare the effect produced by both treatments in terms of the GCI and EGP scales. It is possible to appreciate that in this analysis, the phytopharmaceutical achieved a better score with both scales, principally in weeks 2 and 3 of administration. However, the differences were not significant (Mann-Whitney $U, p \geq 0.09$ ), It is noteworthy that the phytopharmaceutical diminished the IGC from 8 to 4 points and the EGP, from 9 to 4 points.

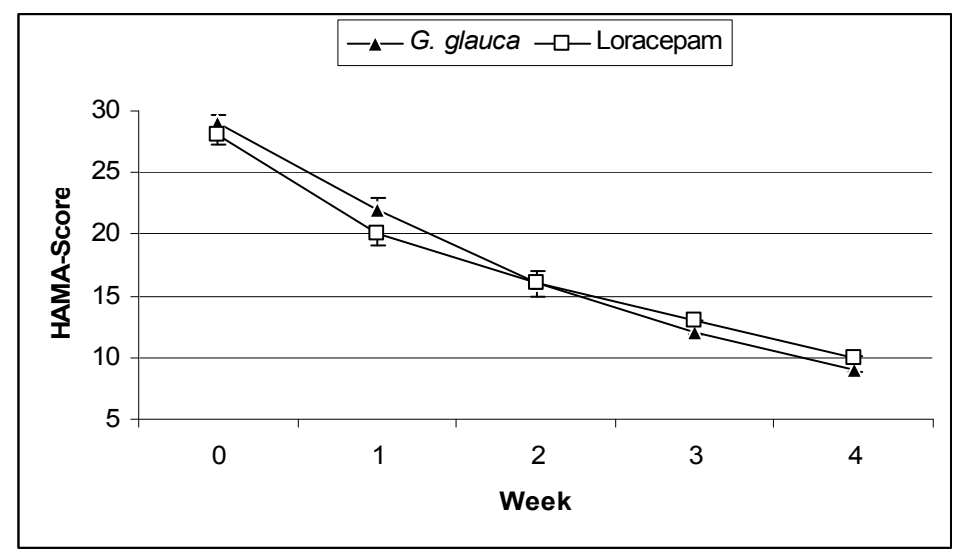

Fig. 7. The figure shows the effect of the treatments administered during 4 weeks on the Hamilton anxiety scale. Values correspond to means and Standard Error (SE) (MannWhitney $U, p \geq 0.54$ ). 


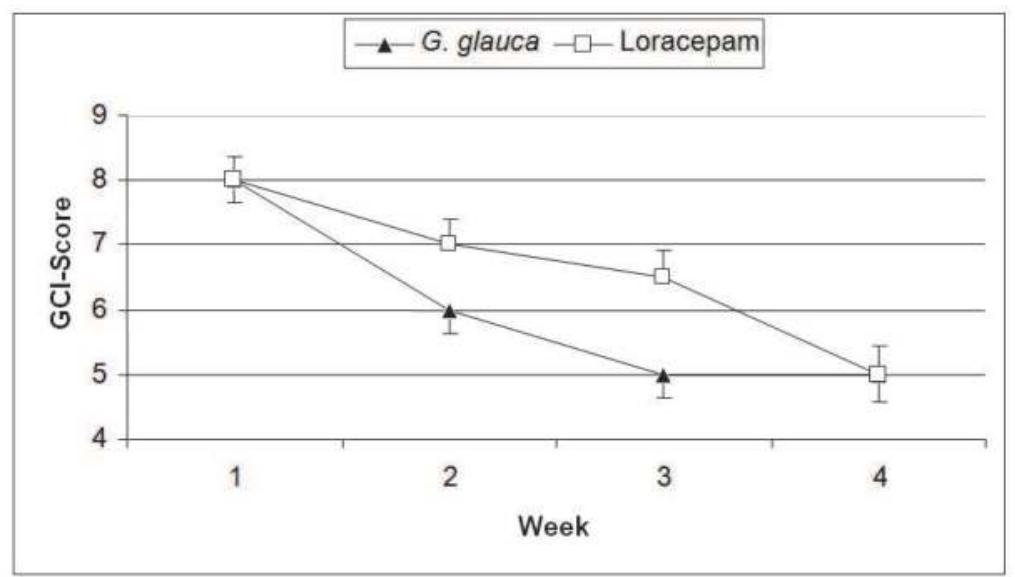

Fig. 8. Figure that shows the effect of treatments administered during 4 weeks on the global clinical impression (GCI) scale. Values correspond to means and Standard error (SE) (MannWhitney $U, p \geq 0.09$ )

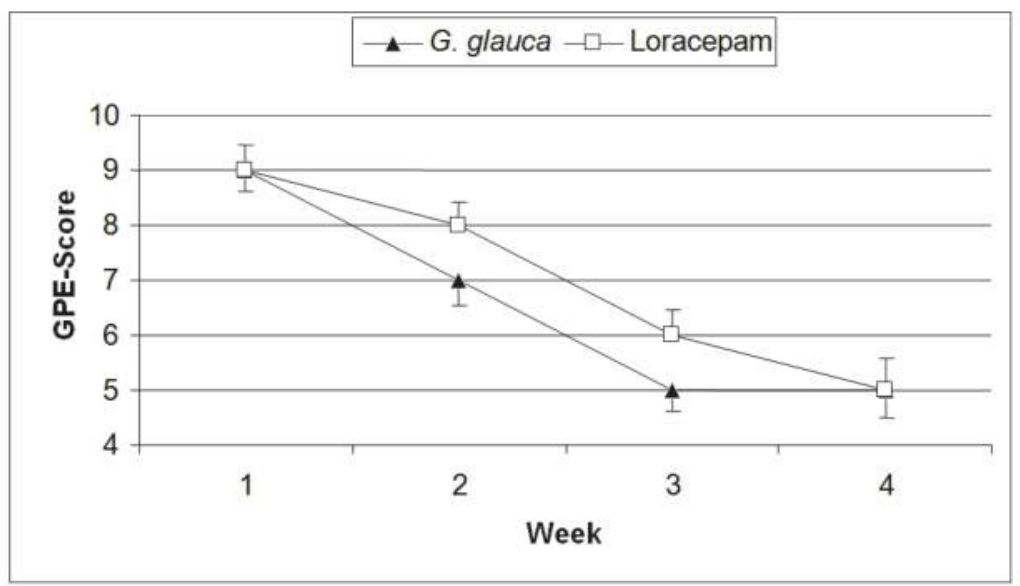

Fig. 9. Figure than shows the effect of the treatments administered during 4 weeks on the global patient evaluation (GPE) scale. Values correspond to means and Standard error (SE) (Mann-Whitney $U, p \geq 0.37$ ).

The stratified analysis, useful to appraise the effect of some confounders on the therapeutic effectiveness of the phytopharmaceutical of G. glauca, demonstrated that the gender of the subject, the subject's weight, and the disease evolution time did not fall into the anxiolytic effect ( $p \geq 0.55)$; however, age and the basal score on the HAM-A scale did exert an influence on the outcome, because subjects $>38$ years or with HAM-A $\leq 30$ points showed greater percentages of therapeutic effectiveness $(p \leq 0.03)$. 


\section{Conclusion}

An innovative anxiolytic phytopharmaceutical has been developed by means of an interdisciplinary work. This product exhibited an innovative mechanism of action through an interaction with the dopaminergic system in CNS. This product was evaluated clinically by means of a double-blind clinical trial in order to compare it with lorazepam (1 mg, twice daily) in terms of therapeutic effectiveness, safety, and tolerability in patients with Generalized anxiety disorder (GAD). After 4 weeks of treatment, the phytopharmaceutical showed important anxiolytic effectiveness, very similar to that produced with lorazepam. However, regarding side effects, the phytopharmaceutical evidenced considerably higher tolerability than lorazepam.

\section{Acknowledgments}

This participation was partially supported by CONACyT with the reference project: SALUD-2007-CO1-69682

\section{References}

Aguilar-Santamaría, L., Ramírez, G., Herrera-Arellano, A., Zamilpa, A., Jiménez, J.E., Alonso-Cortés, D., Cortés-Gutiérrez, E.I., Ledesma, N., Tortoriello, J. (2007). Toxicological and cytotoxic evaluation of standardized extracts of Galphimia glauca. Journal of Ethnopharmacology Vol. 109, Num. 1, pp 35-40.

Belzung, C., Griebel, G. (2001). Measuring normal and pathological anxiety-like behaviour in mice: a review. Behavavioural Brain Research Nov.1; Vol. 125, Num. 1-2, pp 141149

Belzung, C. (2001). The genetic basis of the pharmacological effects of anxiolytics: a review based on rodent models. Behavioural Pharmacology, Nov; Vol.12, Num.6-7, pp 451-60

Cole, J.C., Rodgers, R.J. (1994). Ethological evaluation of the effects of acute and chronic buspirone treatment in the murine elevated plus-maze test: comparison with haloperidol. Psychopharmacology (Berl) Mar; Vol. 114, Num. 2, pp 288-296

Crawley, J.N, Goodwing, F.K. (1980) Preliminary report of a simple animal behaviour for the anxiolytic effects of benzodiazepines. Pharmacology Biochemestry and Behavior; Vol. 13, Num 2, pp 167-170

Cruz, A.P., Frei, F., Graeff, F.G. (1994). Ethopharmacological analysis of rat behavior on the elevated plus-maze. Pharmacology Biochemistry and Behavior, Vol. 49, Num. 1, pp 171-176

Farmacopea de los Estados Unidos Mexicanos (2004). Comisión permanente de la farmacopea de los Estados Unidos Mexicanos 8a Ed. México, Secretaria de Salud. pp 311-572

Fenech, M. (2000). The in vitro micronucleus technique. Mutation Research, Vol. 455, Num. 1-2, pp 81-95.

Gatspar, M., Klimm, H.D. (2003) Treatment of anxiety, tension and restlessness states with Kava special extracts $\mathrm{WS}^{\circledR} 1490$ in general practice: a randomized placebocontrolled double blind multicenter trial. Phytomedicine Vol. 10, Num. 8, pp 631639 
González-Cortazar, M., Tortoriello, J., Alvarez, L. (2005). Norsecofriedelanes as spasmolytics, advances of structure-activity relationships. Planta Medica Vol. 71, Num. 8, pp 711-716.

Grosse-Siestrup, C., Pfeffer, J., Unger, V., Nagel, S., Witt, C., Fischer, A., Groneberg, D.A. (2002) Isolated hemoperfused slaughterhouse livers as valid model to study hepatotoxity. Toxicology Pathology, Vol. 30, Num. 6, pp 749-754

Hascoët, M., Bourin, M., Dhonnchadha, B.A.N. (2001) The Mouse Light-Dark paradigm: a Review. Progress in Neuro-Psychopharmacology \& Biological Psychiatry, Vol. 25, Num. 1, pp 141-166

Herrera-Arellano, A., Jiménez -Ferrer, J.E., Zamilpa, A., Morales-Valdez, M., GarciaValencia, C.E., Tortoriello, J. (2007). Efficacy and tolerability of a standardized herbal product from Galphimia glauca on Generalized Anxiety Disorder. A randomized, double blind clinical trial controlled with lorazepam. Planta Medica Vol. 73, Num. 8, pp 713-717

AHerrera-Ruiz, M., Jiménez-Ferrer, J.E., DE Lima, T.C.M., Aviles-Montes, D., Pérez-Garcia, D., González-Cortazar, M., Tortoriello, J. (2006) Anxiolytic and antidepressant-like activity of a standardized extract from Galphimia glauca. Phytomedicine, Vol. 13, Num. 1-2, pp 23-28.

BHerrera-Ruiz, M., González-Cortazar, M., Jiménez-Ferrer, J.E., Zamilpa, A., Alvarez, L., Tortoriello, J. (2006) Anxiolytic effect of natural galphimines from Galphimia glauca and their derivatives. Journal of Natural Products, Vol. 69, Num. 1, pp 59-61.

Irwin, S. (1968) Comprehensive observational assessment: Ia. A systematic, quantitative procedure for assessing the behavioral and physiologic state of the Mouse. Psycopharmacologia (Berl.) Vol. 13, Num. 3, pp 222-257

Kasper, S., Caraci, F., Forti, B., Drago, F., Aguglia, E. (2010) Efficacy and tolerability of Hypericum extract for the treatment of mild to moderate depression. European of Neuropsychopharmacology Vol. 20, num. 11, pp 747-765

Korte, S.M., De boer, S.F. (2003). A robust animal models of state anxiety: fear-potentiated behaviour in the elevated plus-maze. European Journal of Pharmacology, Vol. 463, Num. 1-3, pp 163-175

Hagenbuch, N., Feldon, J., Yee, B.K. (2006). Use of the elevated plus-maze test with opaque or transparent walls in the detection of mouse strain differences and the anxiolytic effects of diazepam. Behavioural Pharmacology, Vol. 17, Num. 1, pp 31-41

Mashayekh, A., Pham, D.L., Yousem, D.M., Dizon, M., Barker, P.B., Lin, D.D. (2010) Effects of Ginkgo biloba on cerebral blood flow assessed by quantitative MR perfusion imaging: a pilot study. Neuroradiology , Vol. 53, Num. 3, pp 185-191

McClatchey, W.C., Mahady, G.B., Bennett, B.C., Shiels, L., Savo, V. (2009) Ethnobotany as a pharmacological research tool and recent developments in CNS-active natural products from ehnobotanical sources. Pharmacology \& Therapeutics Vol. 123, Num. 2, pp 239-254

OMS (2003). Directices de la OMS sobre buenas practices agrícolas y de recolección (BPAR) de plantas medicinales. Organización Mundial de la Salud. Ginebra 2003.

Oyama, V.I., Eagle, H. (1956) Measurement of cell growth in tissue culture with a phenol reagent (folin-ciocalteau). Proceedings of the Society for Experimental Biology and Medicine. Vol. 91, Num. 2, pp 305-307. 
Perry, P., Wolff, S. (1974) New giemsa method for the differential staining of sister chromatids. Nature Vol. 251, Num. 5471, pp 156-158.

Prieto-Gómez, B., Tortoriello, J., Vázquez-Alvarez, A., Reyes-Vázquez, C. (2003) Galphimine B modulates synaptic transmission on dopaminergic ventral tegmental area neurons. Planta Medica Vol. 69, Num. 1, pp 38-43

Ramos, A., Berton, O., Mormède P., Chaouloff F. (1997). A multiple-test study of anxietyrelated behaviours in six inbred rat strains. Behavioural Brain Research Vol. 85, Num. 1, pp 57-69

Rex, A., Morgenstern, E., Fink H. (2002). Anxiolytic-like effects of Kava-Kava in the elevated plus maze test - a comparison with diazepam. Progress in NeuroPsychopharmacology Biological Psychiatry, Vol. 26, Num. 5, pp 855-860

Rodgers, R.J., Johnson, N.J. (1995). Factor analysis of spatiotemporal and ethological measures in the murine elevated plus-maze test of anxiety. Pharmacology Biochemistry and Behavioural Vol. 52, Num. 2, pp 297-303

Rodgers, R.J., Cao, B.J., Dalvi, A., Holmes, A. (1997). Animal models of anxiety: an ethological perspective. Brazilian Journal of Medical and Biological Research Vol. 30, Num. 3, pp 289-304

Salter, S., Brownie S. (2010) Treating primary insomnia - the efficacy of valerian and hops. Australian Family Physician Vol. 39, Num. 6, pp 433-437

Shultes, R.E., Hofmann, A. (2008) Plantas de los dioses. Fondo de Cultura Económica México. ISBN978-968-16-6303-9, pp 31-60

Stirnimann, G., Kessebohm, K., Lauterburg, B. (2010) Liver injury caused by drugs: an update. Swiss Medical Weekly; 140:w13080. doi:10.4414/smw.2010.13080

Teschke, R., Sarris, J., Lebot, V. (2011) Kava Hepatotoxicity solution: A six point plan for new kava standardization. Phytomedicine Vol. 18, Num. 2-3, pp 96-103

Tortoriello, J. (1999) Neurophytopharmaceuticals a review. Lozoya, X., Gómez E., Bruner, M. The phytopharmaceuticals of the next century. IMSS/Farmasa Schwabe, pp 7798

Tortoriello, J. (1998) Mesencephalic effects of Galphimine-B, a triterpenoid from Galphimia glauca. In Lozoya X, Gomez E, Brunner M. Neurophytopharmaceuticals. IMSS/Farmasa Schwabe ISBN 968-824-741-3, pp 77-96

Tortoriello, J., Ortega, A., Herrera-Ruíz, M.,Trujillo, J., Reyes-Vázquez, C. (1998) Galphimine-B modifies electrical activity of ventral tegmental area neurons in rats. Planta Medica, Vol. 64, Num. 4, pp 309-313.

Tortoriello, J., Zamilpa, A., Herrera, A., Romero-Cerecero, O. (2003) Determination of hypericin and hyperforion content in different phytopharmaceuticals and dietary supplements containing Hypericum perforatum extract. Salud Mental, Vol. 26, Num. 4, pp 59-63

Tortoriello, J., Lozoya, X. (1992) Effect of Galphimia glauca Methanolic extract on Neuropharmacological Tests. Planta Medica, Vol. 58, Num. 3, pp 234-236.

Tortoriello, J., Ortega, A. (1993) Sedative effects of Galphimine B, a Nor,seco-triterpenoid from Galphimia glauca. Planta Medica, Vol. 59, Num. 5, pp 398-400.

Toscano, R.A., Ortega, A., Maldonado, E., Gaviño, R., Lozoya, X., Tortoriello, J. (1993) Structure of Galphimine B. Acta Crystallographica, C49, pp 774 - 776. 
Weiss, S.M., Wadsworth, G., Fletcher, A., Dourish, C.T. (1998). Utility of ethological analysis to overcome locomotor confounds in elevated maze models of anxiety. Neuroscience and Biobehavioral Reviews Vol. 23, Num.2, pp 265-271

Zhang, Z.J. (2004). Therapeutic effects of herbal extracts and constituents in animal models of psychiatric disorders. Life Science Vol. 75, Num 14, pp 1659-1699 


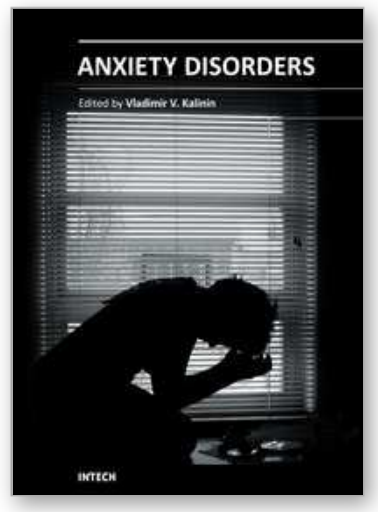

\author{
Anxiety Disorders \\ Edited by Prof. Vladimir Kalinin
}

ISBN 978-953-307-592-1

Hard cover, 324 pages

Publisher InTech

Published online 01, August, 2011

Published in print edition August, 2011

During the last 2-3 decades drastic research progress in anxiety issues has been achieved. It concerns mostly the study of different subtypes of anxiety and their treatment. Nevertheless, the data on anxiety pathogenesis is less elaborated, although here a multidimensional approach exists. It includes neurochemistry, pathophysiology, endocrinology and psychopharmacology. Again, we are able to recognize the multifarious sense of anxiety, and the present collective monograph composed of 16 separate chapters depicting the different aspects of anxiety. Moreover, a great part of book includes chapters on neurochemistry, physiology and pharmacology of anxiety. The novel data on psychopathology and clinical signs of anxiety and its relationship with other psychopathological phenomena is also presented. The current monograph may represent an interest and be of practical use not only for clinicians but for a broad range of specialists, including biochemists, physiologists, pharmacologists and specialists in veterinary.

\title{
How to reference
}

In order to correctly reference this scholarly work, feel free to copy and paste the following:

Jaime Tortoriello, Armando Herrera-Arellano, Maribel Lucila Herrera-Ruiz, Alejandro Zamilpa, Manases González-Cortazar and Jesús Enrique Jiménez-Ferrer (2011). New Anxiolytic Phytopharmaceutical Elaborated with the Standardized Extract of Galphimia glauca, Anxiety Disorders, Prof. Vladimir Kalinin (Ed.), ISBN: 978953-307-592-1, InTech, Available from: http://www.intechopen.com/books/anxiety-disorders/new-anxiolyticphytopharmaceutical-elaborated-with-the-standardized-extract-of-galphimia-glauca1

\section{INTECH}

open science | open minds

\section{InTech Europe}

University Campus STeP Ri

Slavka Krautzeka 83/A

51000 Rijeka, Croatia

Phone: +385 (51) 770447

Fax: +385 (51) 686166

www.intechopen.com

\section{InTech China}

Unit 405, Office Block, Hotel Equatorial Shanghai

No.65, Yan An Road (West), Shanghai, 200040, China

中国上海市延安西路65号上海国际贵都大饭店办公楼 405 单元

Phone: +86-21-62489820

Fax: $+86-21-62489821$ 
(C) 2011 The Author(s). Licensee IntechOpen. This chapter is distributed under the terms of the Creative Commons Attribution-NonCommercialShareAlike-3.0 License, which permits use, distribution and reproduction for non-commercial purposes, provided the original is properly cited and derivative works building on this content are distributed under the same license. 